\title{
The marine Quaternary in Denmark: a review of new evidence from glacial-interglacial studies
}

\author{
KAREN LUISE KNUDSEN
}

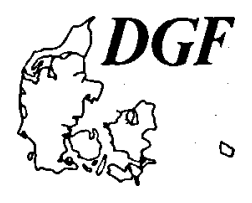

Knudsen, K. L. The marine Quaternary in Denmark: a review of new evidence from glacial-
interglacial studies. Bulletin of the Geological Society of Denmark, Vol. 41, pp. 203-218.
Copenhagen, 1994-11-30. https://doi.org/10.37570/bgsd-1995-41-17

The marine Quaternary of the onshore areas in Denmark is restricted to deposits from the Middle and the Late Quaternary. Selected marine glacial-interglacial paleoenvironmental reconstructions from this sequence are reviewed with special emphasis on relatively recent studies. In addition, an outline of the stratigraphy of the Skagen 3 borehole is given for the first time. The Quaternary at Skagen has a total thickness of almost $200 \mathrm{~m}$. A lower about $7 \mathrm{~m}$ thick marine Saalian-Eemian-Early Weichselian sequence (between ca. 185 and $178 \mathrm{~m}$ depth in the core) is succeeded by a fluvial deposit (178-132 m) and an apparently continuous extremely thick marine Late Weichselian and Holocene sequence (from $132 \mathrm{~m}$ depth to the top of the core).

Karen Luise Knudsen, Department of Earth Sciences, University of Aarhus, DK-8000 Århus C, Denmark. March 17th, 1994.

\section{Introduction}

This paper reviews some of the more recent advancements in the study of the marine Quaternary in Denmark, including some of new information obtained in the framework of a marine geological project "the GeoKat project" in North Jutland and in the Kattegat area (e.g., Lykke-Andersen et al. 1993a).

Core material from the Danish North Sea sector shows that the marine sediments in this region comprise deposits both from the Early and from the Middle and Late Quaternary (Buch 1972; Knudsen 1985a, 1986a; Sejrup \& Knudsen 1993; Salomonsen \& Jensen in press), but only minor portions of the Quaternary record are represented at each site.

In onshore Denmark only deposits from the Middle and the Late Quaternary have hitherto been registered. However, in contrast to the North Sea records, it is remarkable that long marine glacial-interglacial records are registered here. As a number of these records seem to represent continuous marine shelf sequences, they offer great potential for detailed description of environmental change during the periods of deposition.

The main depositional regions for marine Quaternary deposits in Denmark seem to have at least partially been controlled by the pre-Quaternary structures in the areas under question. Thus, the areal extent of the marine Elsterian-Holsteinian transgression coincides with areas with a deep-lying pre-Quaternary surface both in SW Jutland (Knudsen 1987a) and in the Limfjord area (Knudsen 1987b) (see Fig. 1). Similarily, extremely thick ma- rine sequences from the Saalian, Eemian and Early to Middle Weichselian are deposited in a structurally determined northwest-southeast trending basin, which crosses the northern part of Jutland and the Kattegat approximately parallel with the Sorgenfrei-Tornquist Zone $(\mathrm{H}$. Lykke-Andersen 1987, in press; Lykke-Andersen et al. 1993b).

\section{Elsterian and Holsteinian}

The locations of most of the occurrences of marine Elsterian and Holsteinian deposits in Denmark are given in Fig. 1, together with a map of the suggested areal extent of the Elsterian-Holsteinian transgression in west and southwest Denmark (Knudsen 1987a, 1987b; Bruun-Petersen 1990). The foraminiferal assemblages indicate that deep embayments of pre-Quaternary origin in Jutland were already transgressed by the sea as early as in the Late Elsterian, and that the regression occurred before the end of the Holsteinian Interglacial period. In general, the occurrences of deposits that are regarded as Late Elsterian and Holsteinian in age in the Limfjord area are glacially dislocated (e.g., at Kås Hoved, Gyldendal and Hostrup (Jensen \& Knudsen 1984; Knudsen 1977, 1987b)), while in situ records are registered in boreholes in SW Jutland (see below).

Scattered occurrences of marine Elsterian and Holsteinian deposits around the southern part of the present Kattegat, such as Rugård, Slettenshage and Sorø (Fig. 1) (Kronborg \& Knudsen 1985; Knudsen 1987b; Lykke- 


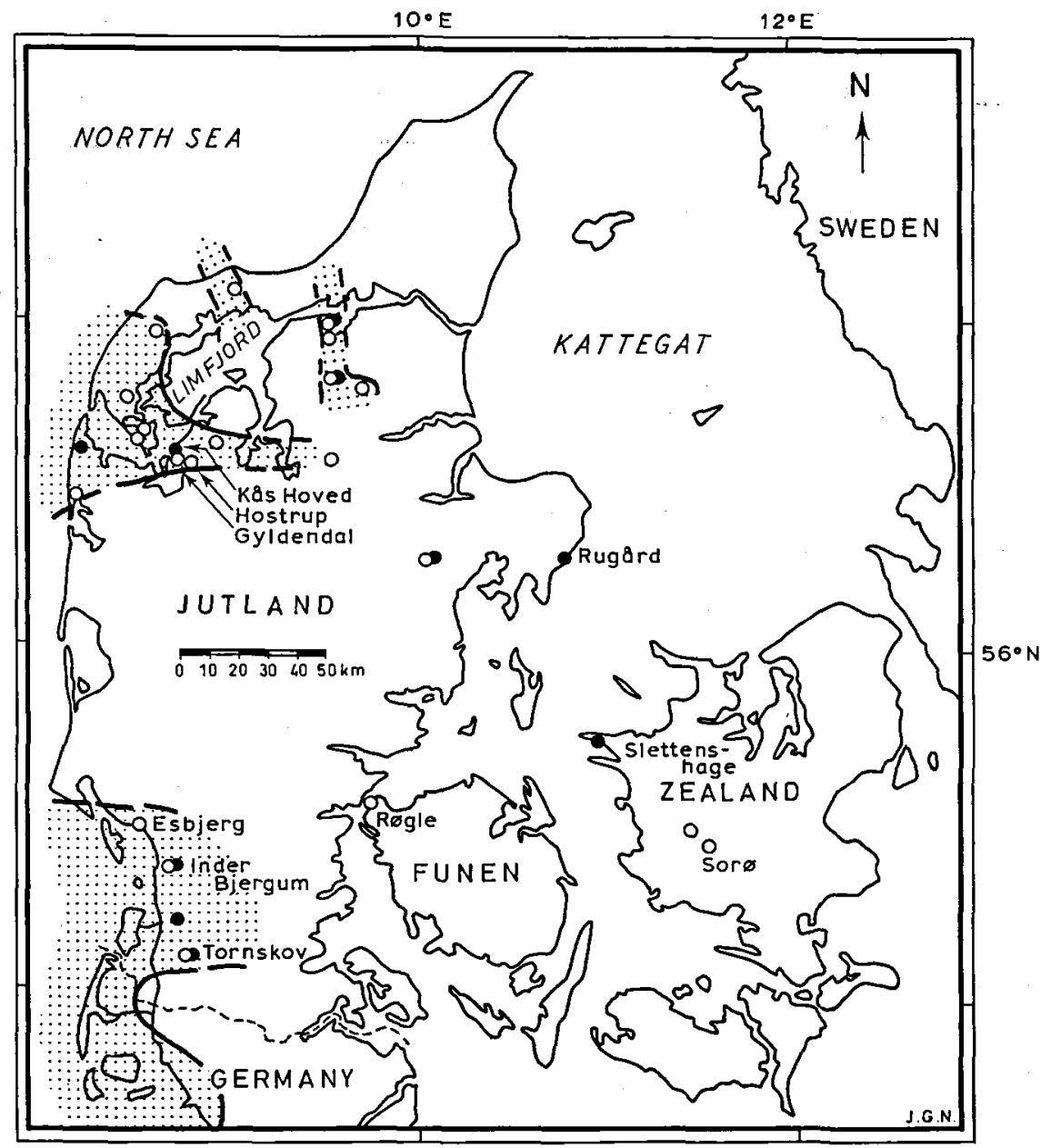

Fig. 1. Sites with Elsterian and Holsteinian marine deposits in Denmark. Open circles $=$ marine Elsterian deposits; filled circles $=$ marine

Holsteinian deposits; solid line $=$ probable position of the Elsterian-Holsteinian coastline along the North Sea coast and in the Limfjord area. (Mainly after Knudsen 1987a, 1987b).

Andersen 1990), indicate that the southern Kattegat region must also have made up part of this interglacial sea. However, our present knowledge of the distribution of these deposits precludes a reliable reconstruction of the Holsteinian coastline in this area.

It should be noted that some of the sites, which are traditionally referred to the Elsterian (and marked as such in Fig. 1) on the basis of their fossil content, may prove to be older. Amino acid measurements on molluscs and/or foraminifera from Røgle, Esbjerg and Gyldendal, thus, suggest a Cromerian age for these deposits (Miller \& Mangerud 1986; Knudsen \& Sejrup 1988). Correspondingly, a thermoluminescence (TL) dating of the Tellina Clay at Røgle also suggests an older age than the Elsterian (at least 325,000 years, Christian Kronborg personal communication). Some of the other undated pre-Holsteinian deposits in Denmark may also prove to be older than the Elsterian, and more detailed studies and additional dates are needed to solve the problem of stratigraphical interpretation.

\section{The Tornskov core}

The most complete and well-dated in situ marine Elsterian-Holsteinian sequence in Denmark occurs at Tornskov in SW Jutland. A simplified foraminiferal range chart from this site, constructed on the basis of data from the Tornskov borehole (Knudsen 1987a), is shown in Fig. 2.

The lowermost $15 \mathrm{~m}$ of the marine sequence contains arctic foraminiferal species at the bottom (Zone $\mathrm{A}$ ), and there is a gradual increase in the content of boreal species in Zone B. Elphidium excavatum (Terquem), forma clavata Cushman, Cassidulina reniforme Nørvang, Haynesina orbiculare (Brady) and Elphidium hallandense Brotzen are dominant. The assemblages indicate that marine conditions reached the area during the Late Elsterian.

A marked shift in fauna at $57 \mathrm{~m}$ below present day sea level in the core indicates the transition to the Holsteinian Interglacial. The assemblages in the $50 \mathrm{~m}$ thick Holsteinian sequence (Zones C-E) are dominated by Elphidium excavatum, forma selseyensis (Heron-Allen \& Earland), E. magellanicum Heron-Allen \& Earland, Ammonia beccarii (Linné), and other boreal shallow water species, 
Fig. 2. Simplified

foraminiferal range chart of the Tornskov borehole, SW Jutland. Pollen zonation according to Andersen (1963).

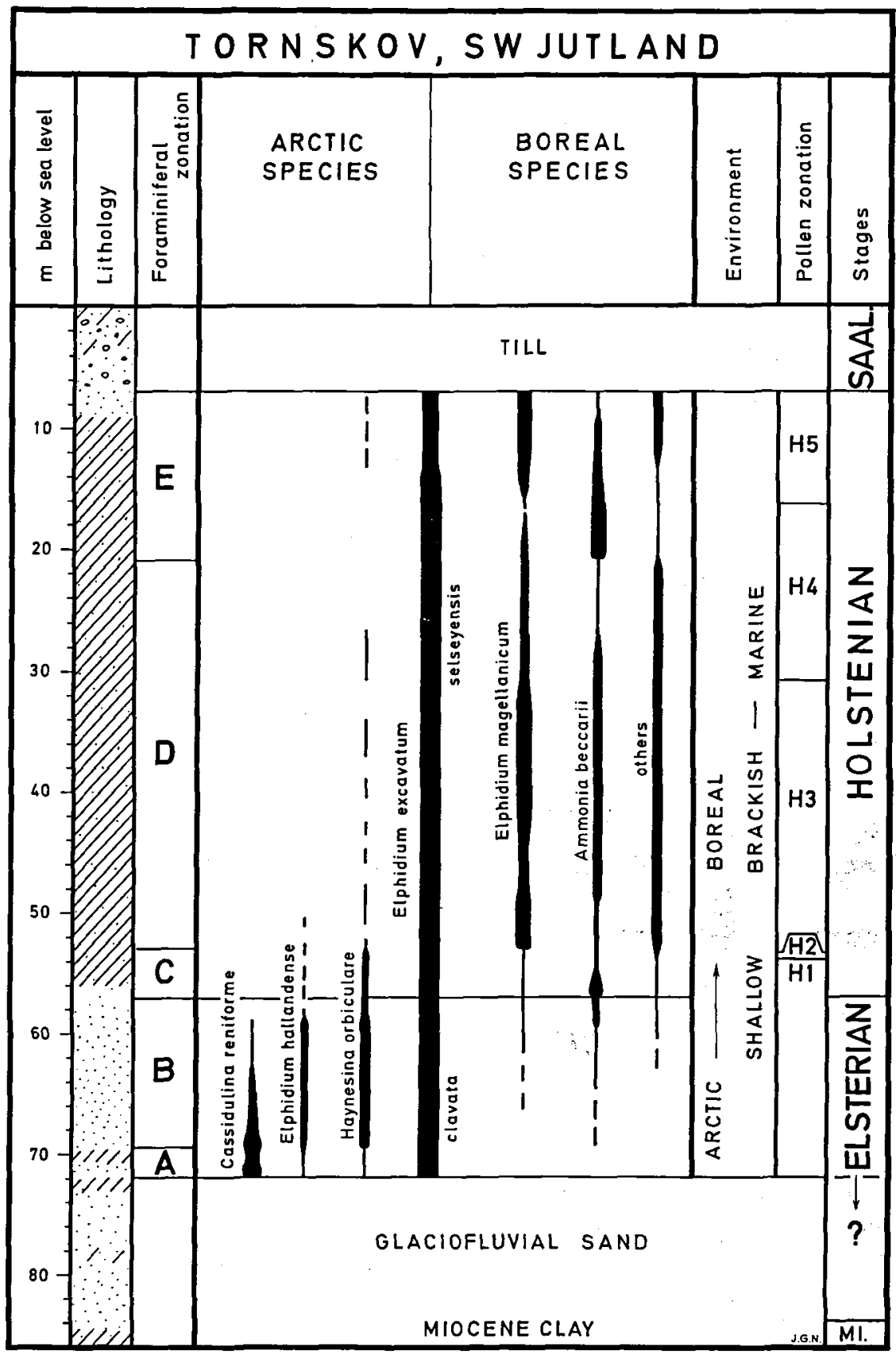

EDCLAY indicating that the temperature conditions must have been relatively close to the present temperatures in the same area. A similar conclusion was reached on the basis of ostracod faunas from the same core (Penney 1987).

\section{Correlation}

The Tornskov sequence was first assigned a Holsteinian age by Andersen $(1963,1965)$ on the basis of pollen. The marine Tornskov sequence has been bio-stratigraphically correlated with a similar sequence in a neighbouring borehole at Inder Bjergum in SW Jutland (Fig. 1) (Buch 1955; Knudsen 1987a) and with several marine Holstei- 


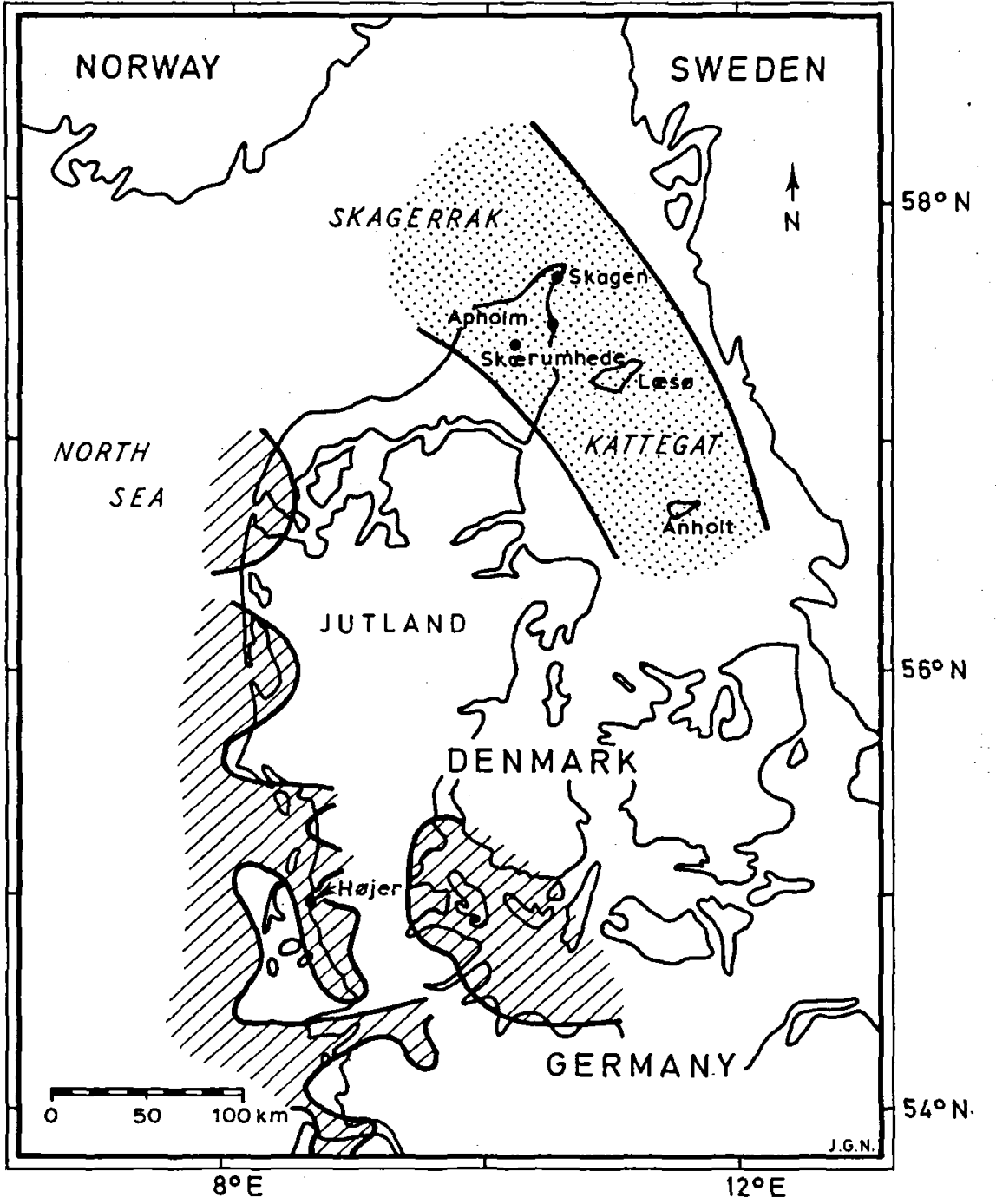

Fig. 3. The maximum extent of the Eemian transgression in Denmark and northern Germany and the location of sites mentioned in the text. The stipple marks a deeper marine Eemian facies (about $100 \mathrm{~m}$ water depth or more) deposited in a northwestsoutheast trending basin across northern Denmark. The hatching indicates shallow marine coastal Eemian facies (0-40 $\mathrm{m}$ water depth) to the south and southwest. (After Konradi 1976; Streif 1984; Penney 1990; Knudsen 1992). nian occurrences in North Germany (Knudsen 1993). Amino acid measurements on foraminifera from these deposits give comparable values, and similar values have also been obtained from interglacial assemblages in the North Sea area (Sejrup \& Knudsen 1993). These results combined with the faunal indications of the deposits led Sejrup \& Knudsen (1993) to suggest a correllation of the Holsteinian Interglacial with oxygen isotope stage 7 in the deep-sea stratigraphy (Martinson et al. 1987). A similar result was also obtained by Linke et al. (1985) on the basis of ESR (Electron Spinning Resonance) datings on Holsteinian deposits in Germany.

\section{Saalian to Holocene}

Marine deposits spanning the Late Saalian to the Middle
Weichselian are found at several sites in the northern part of Denmark (Knudsen 1985b, 1992; A.-L. Lykke-Andersen 1987; Lykke-Andersen \& Knudsen 1991), where a deep northwest-southeast trending basin, called the Kattegat Depression (Lykke-Andersen et al. 1993b), formed a southeastern branch of the Norwegian Trench during this period of time. Contrary to the present Norwegian Trench, this Kattegat Depression is almost completely filled with Quaternary sediments. In the central part of the depression deposition has continued through the Late Weichselian and the Holocene, as exemplified in the Skagen 3 borehole.

Other lowlying coastal areas of Denmark were flooded during the maximum transgression of the Eemian. This is especially seen in the southern and southwestern part of Denmark, where the marine interglacial sediments only represent a minor portion of the Eemian, and neither the 

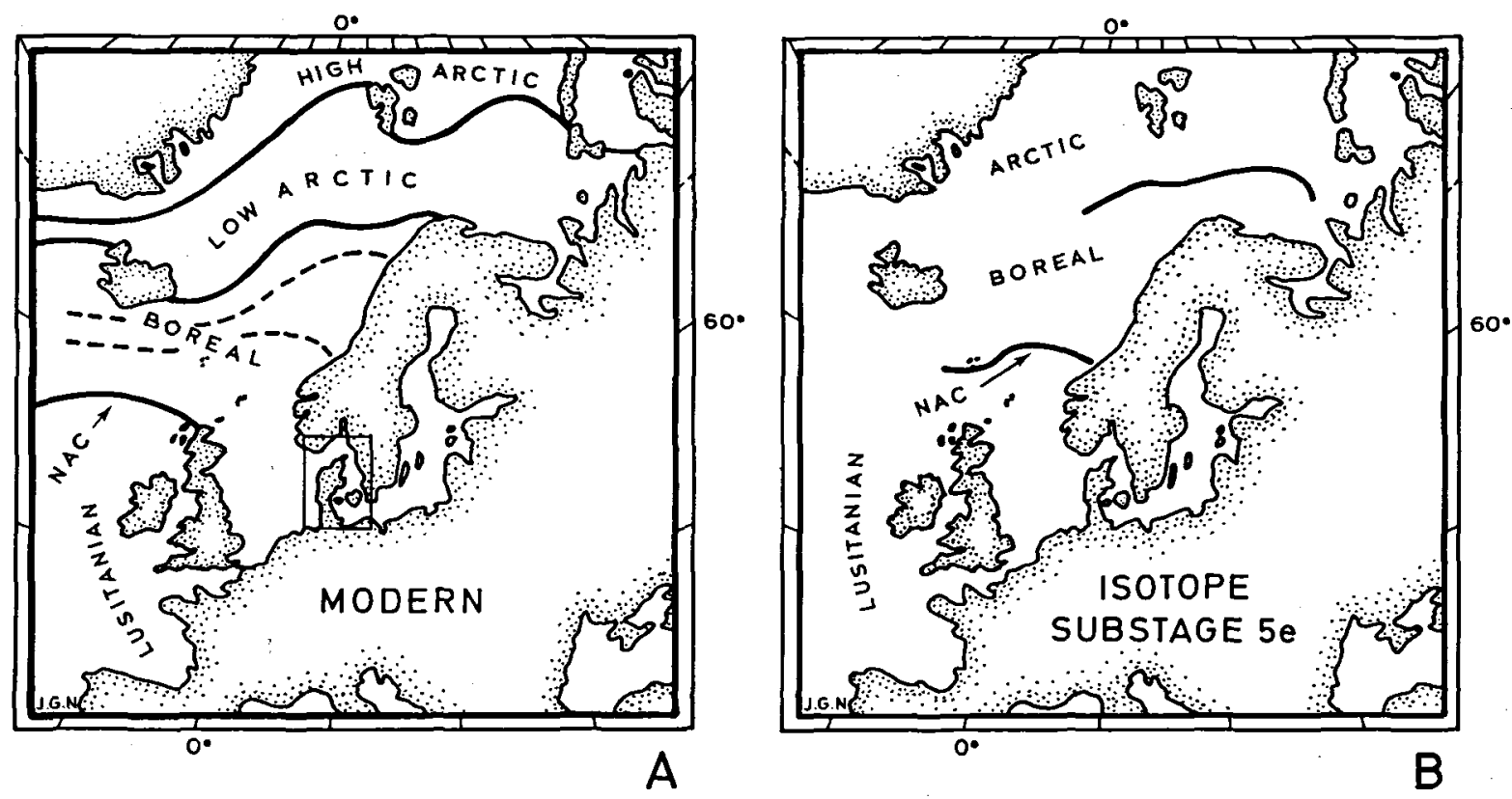

Fig. 4. Map A shows the recent faunal provinces in the North Atlantic (revised after Feyling-Hanssen 1955). The dotted lines indicate subdivisions of the boreal faunal province into low boreal (warmest), mid boreal and high boreal (coldest) subprovinces. The rectangle outlines the area of Fig. 3. NAC = North Atlantic Current. Map B shows the suggested distribution of faunal provinces in the Northwest European Atlantic region during the Eemian (isotope substage 5e). The faunal boundaries are constructed on the basis of foraminiferal and stable isotope evidence (After Sejrup in prep.). NAC = North Atlantic Current.

Saalian-Eemian transition (stage 6/5e) nor the EemianWeichselian transition (substage $5 \mathrm{e} / 5 \mathrm{~d}$ ) are represented in the marine sediments (Konradi 1976; Penney 1990). A reconstruction of the suggested Eemian coastline in Denmark and N. Germany is shown in Fig. 3.

It is now generally accepted that the Eemian Interglacial corresponds to oxygen isotope substage $5 \mathrm{e}$ in the deep-sea stratigraphy (e.g., Shackleton 1969; Mangerud et al. 1979; Turon 1984), and the dating of the Eemian to about 130-115 ka BP thus follows the chronology of Martinson et al. (1987).

A characteristic feature for the Eemian in the northwest European area is a faunal indication of water temperatures at least 2-3 degrees higher than today (e.g., Van Voorthuysen 1957; Mangerud et al. 1981; Knudsen 1984, 1985c, 1988; Penney 1990). The foraminifera that lives in the Kattegat and the Skagerrak today (Conradsen et al. 1994) belong to the boreal faunal province (Fig. 4, map A). The Eemian assemblages, however, indicate a northwards migration of the lusitanian faunal province and a penetration of warm water into the whole of the North Sea basin. This was presumably caused by a strenghened North Atlantic Current (Fig. 4, map B), allowing warm water to pass around northern Scotland and into the North Sea (e.g., Knudsen 1992; Sejrup \& Knudsen 1993). A similar, but less pronounced northward migration of warm Atlantic waters has also been reported from the Holocene climatic optimum (Koç et al. 1993).
Shallow water Eemian in southern Denmark

Figure 5 is a simplified foraminiferal and ostracod range chart (Penney 1990) from Højer, a typical Eemian shallow water sequence in southern Denmark (Figs. 3 and 5). Three phases of accumulation have been recognized here. An initial brackish tidal flat deposit (foraminiferal Zone A) is dominated by Elphidium gunteri (Cole) and Ammonia beccarii. This is followed by shallow sublittoral deposits (Zones $\mathrm{C}$ and $\mathrm{D}$ ) characterized by Ammonia beccarii, Elphidium excavatum, forma selseyensis and Haynesina germanica (Ehrenberg). A final phase of shallowing is seen at the top part of the Eemian sequence (Zone.F), where Elphidiun williamsoni Haynes and $E$. incertum (Williamson) increase and E. excavatum, forma selseyensis decreases in frequency.

Both the foraminiferal and the ostracod content indicate that the transgression occurred during the warmest part of the interglacial, and several species can be considered as lusitanian forms that migrated into the North Sea during the Eemian. The foraminifera Elphidium translucens Natland, E. lidoense Cushman, Quinqueloculina seminulum, var. jugosa Cushman and $E$. aspera d'Orbigny, thus, indicate that water temperatures were a few degrees higher than during the Holocene climatic optimum and at present in the area.

Similar boreal-lusitanian shallow water assemblages have been described from several other sites both in 


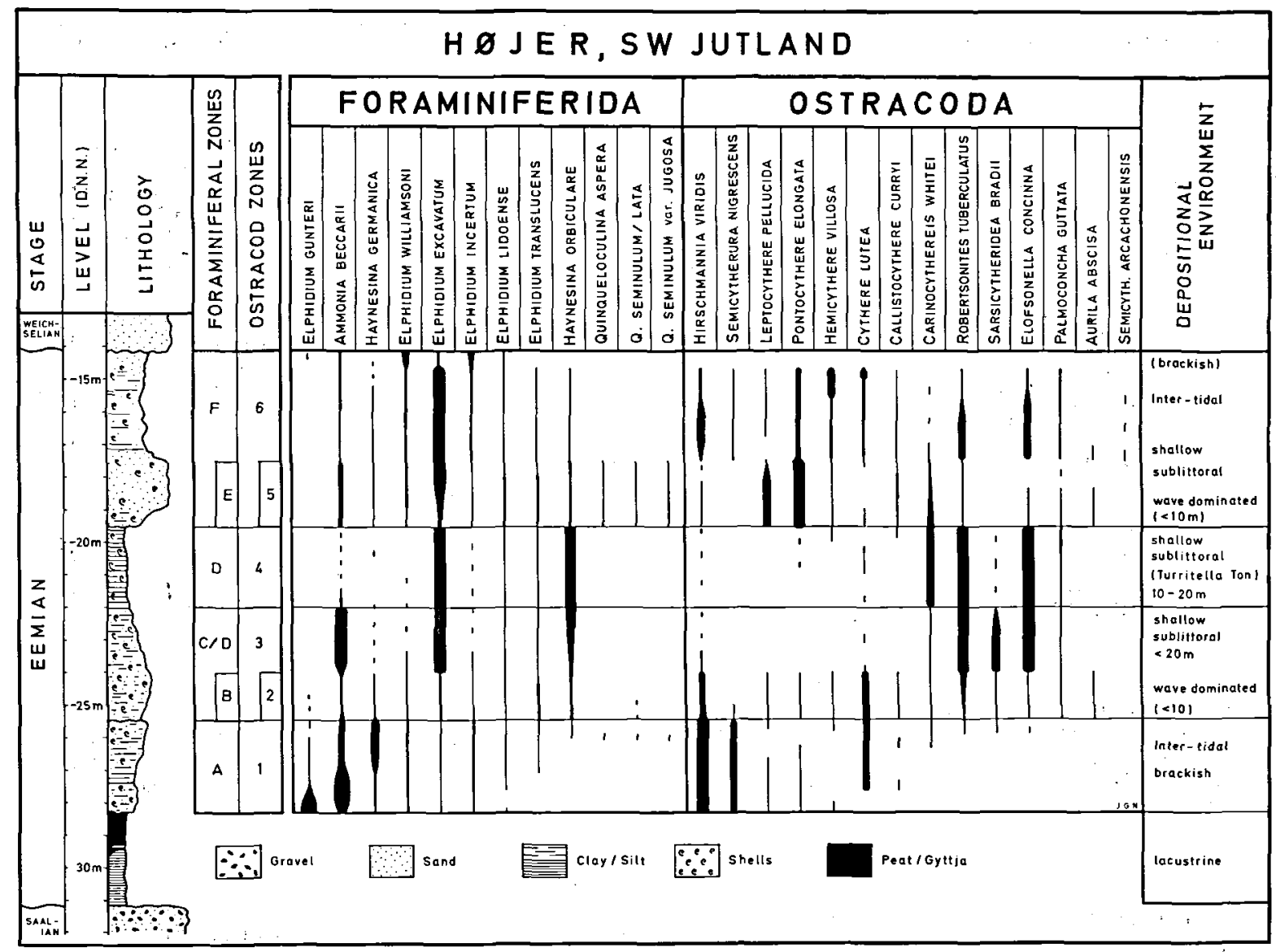

Fig. 5. Simplified range chart showing the distribution of selected foraminiferal and ostracod species in the shallow water Eemiatnat Højer, SW Jutland (After Penney 1990).

southern Denmark (e.g., Konradi 1976), in North Germany (e.g., Lafrenz 1963; Wiegank 1972; Knudsen $1985 b, 1985 c, 1988)$, and in cores from the North Sea (Knudsen 1985a). An Eemian age for these sediments is verified by several amino acid dates (Miller \& Mangerud 1986; Knudsen \& Sejrup 1988).

\section{The North Jutland basin}

A compilation of the results from the study of several boreholes in North Jutland (Fig. 3) is illustrated in the foraminiferal range chart of Fig. 6 . The depth scale in Fig. 6 is from the Apholm well (Knudsen 1984) where the Eemian sequence had a thickness of $50 \mathrm{~m}$. In general, the thickness of the Eemian in the area varies between 20 and $65 \mathrm{~m}$. The Eemian rests on arctic marine sediments (referred to the Saalian) only in part of the area (see Knudsen 1985b; A.-L. Lykke-Andersen 1987), but it is always succeeded by a marine Weichselian sequence.

$A$ boreal-lusitanian environment during the Eemian (Zone N3) is indicated by the dominance of Bulimina marginata d'Orbigny, Cassidulina laevigata d'Orbigny and Hyalinea balthica (Schroeter) and by the presence of Quinqueloculina padana Perconig. Water depths were in excess of about $100 \mathrm{~m}$. In addition, the faunas indicate that the North Sea-Kattegat area was strongly effected by warm Atlantic water. The correlation of Zone N3 in North Jutland with oxygen isotope substage $5 \mathrm{e}$ has been supported by amino acid measurements by Knudsen \& Sejrup (1988) and Sejrup \& Knudsen (1993).

The faunal succession described from Skærumhede and from Apholm (Knudsen \& Lykke-Andersen 1982; Knudsen 1884) reveals that a decrease in water depth must have occurred during the last third of the interglacial (assuming that the interglacial zone corresponds to the whole of the Eemian Interglacial). There is also a faunal indication of more varying environmental conditions during the later part of the Eemian.

The disappearance of deeper water species and a distinct increase in the frequency of shallow water Elphidiidae above the Eemian-Weichselian boundary (Fig. 6) indicate that the gradual decrease in water depth in the Late Eemian (about $15 \mathrm{~m}$ ) was followed by a major drop (at least $50 \mathrm{~m}$ ) in sea level at the Eemian-Weichselian 
Fig. 6. Simplified

foraminiferal range chart and stratigraphical correlation of cores in the North Jutland region. (After Knudsen \& Lykke-Andersen 1982; Knudsen 1984, 1986a, 1992; Lykke-Andersen \& Knudsen 1991).

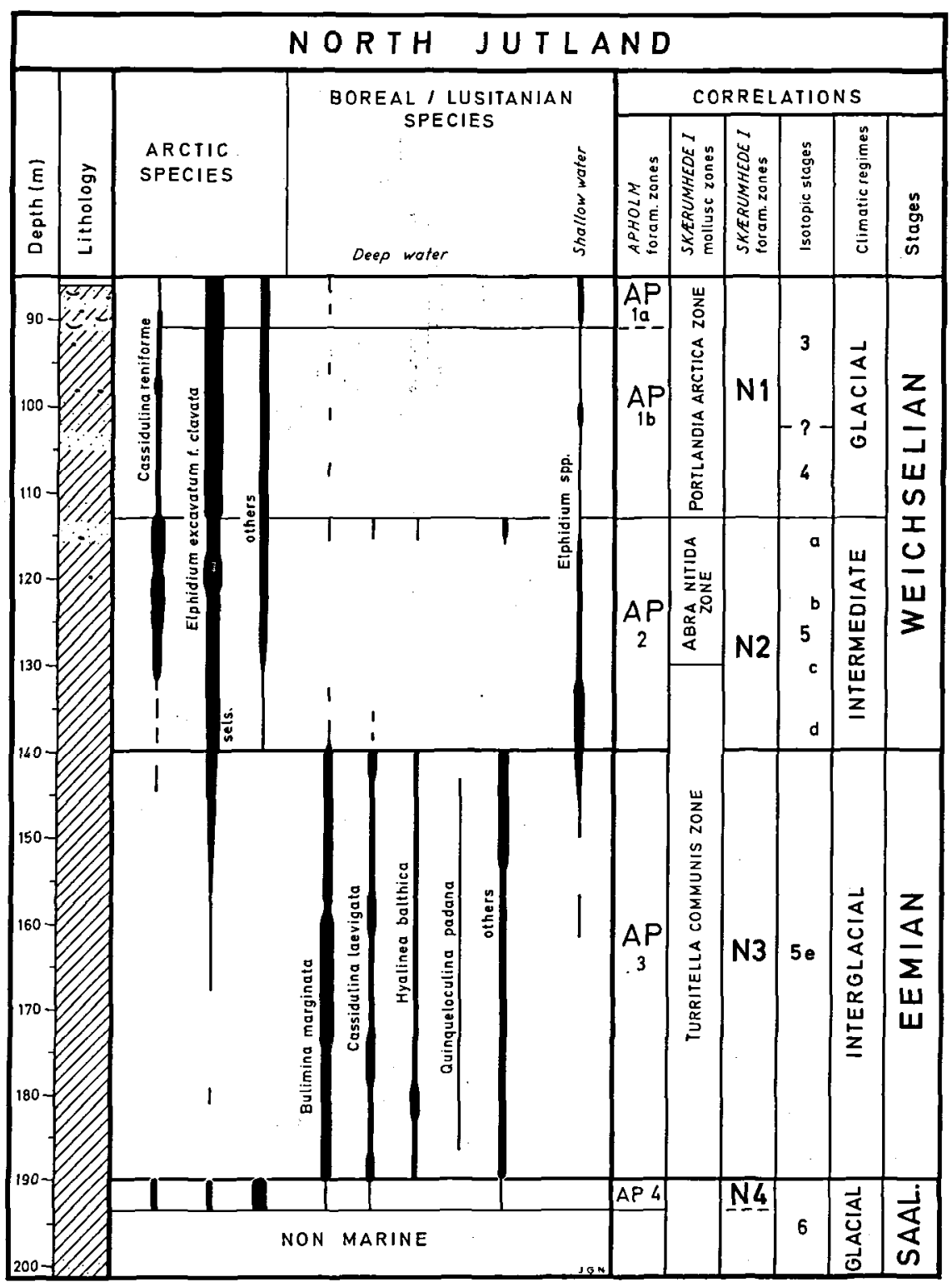

Ezclay $\square$ Sandisilt $\because \because$ pebeles $\square$ molluscs boundary (Knudsen 1992). This corresponds to a similar sea level drop reported by Zagwijn $(1977,1983)$ in the southern North Sea region and by Chappell \& Shackleton (1986) from deep sea records.

The lowermost part of the Early Weichselian in North Jutland is characterized by boreal shallow water species, but these are gradually replaced by arctic species such as Elphidium excavatum, forma clavata and Cassidulina reniforme through Zone N2 (Fig. 6). True arctic glacial conditions were presumably not attained until Zone N1 (isotope stage 4).
The Anholt cores

The about $104 \mathrm{~m}$ thick Quaternary sequence of the Anholt cores II and III comprises deposits of non-marine and marine origin. A basal non-marine sequence of diamict and glaciofluvial sand (see Nielsen 1992) is overlain by a 8-9 m thick marine Late Saalian and Eemian sequence, consisting of sandy silt, silt and clay (Fig. 7). The chronology of this marine deposit is based on amino acid measurements and biostratigraphical correlations (Seidenkrantz 1992, 1993a, 1993b). 


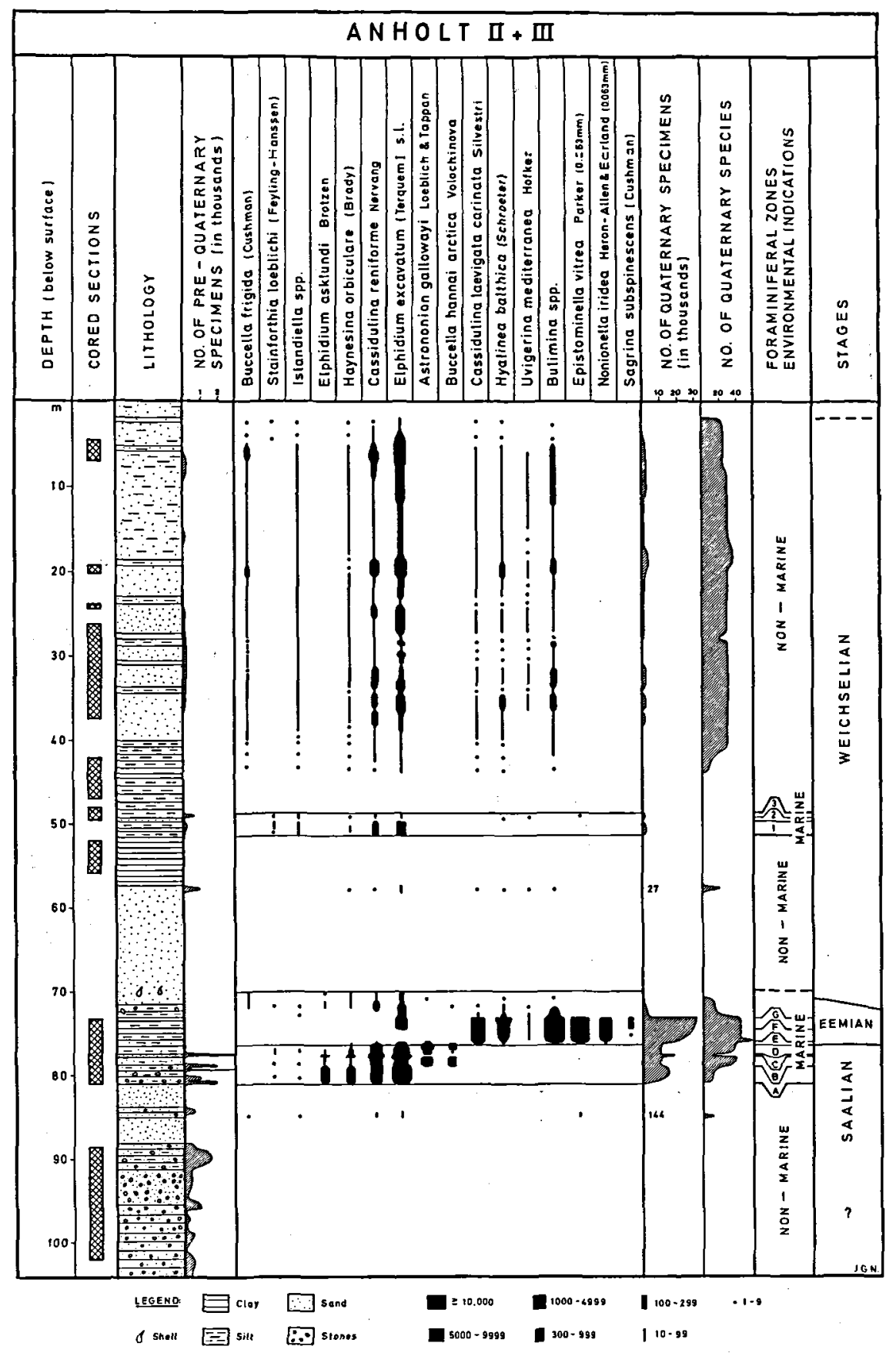

Fig. 7. Simplified range chart with selected species of foraminifera from the Quaternary sequence at Anholt (compiled from the two boreholes, Anholt II and Anholt III). The number of Quaternary specimens and the number of redeposited preQuaternary specimens (Maastrichtian) are indicated per $100 \mathrm{~g}$ sediment. Ditch cutting samples were studied from the intervals between the cored sections. (Seidenkrantz 1993b).

Especially noteworthy for the Saalian-Eemian sequence of Anholt is that the benthic foraminifera from the boreholes (Figs. 7, 8, 10) reveal a detailed record of a climatic fluctuation at the Saalian-Eemian (isotope stage 6/5e) transition (Seidenkrantz 1993a, 1993b; Seidenkrantz \& Knudsen in press; Seidenkrantz et al. in press).

The lower part of the marine glacial-interglacial section from Anholt consists of a glaciomarine sandy silt deposit with numerous ice-rafted debris (pebbles and stones), and a low-diversity foraminiferal assemblage (Zone A) characterized by the arctic species Elphidium excavatum, forma clavata and Cassidulina reniforme (Fig. 8). This indicates deposition in an ice-proximal arctic environment. The appearance of boreal-arctic species such as Astrononion gallowayi Loeblich \& Tappan and Buccella hannai arctica Voloshinova together the gradual disappearance of ice-rafted material through Zone B was interpreted to indicate ameliorated condi- 
Fig. 8. Percentage diagram of selected foraminiferal species from the Late Saalian-Early Eemian transition of the Anholt II borehole and the estimated oscillation in water temperature. (Seidenkrantz et al. in press).

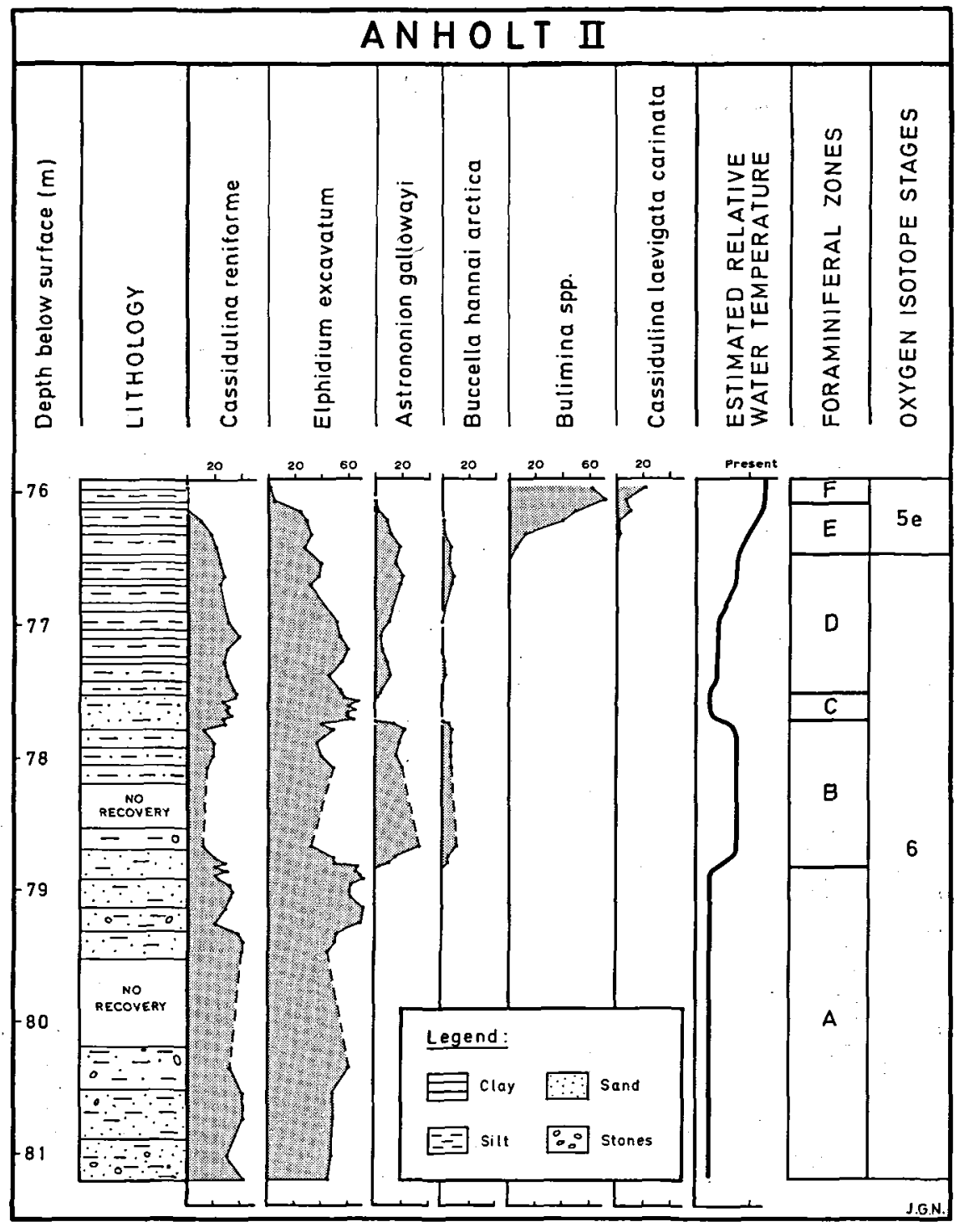

tions, and Zone B was thus suggested to represent an interstadial period, the "Zeifen Interstadial" (see Seidenkrantz 1993a; Seidenkrantz et al. in press).

The foraminiferal assemblages indicate that the Late Saalian amelioration was interrupted by a return to cold conditions (Zones C and D, Fig. 8). This interval seems to represent an initial climatic deterioration to extreme arctic conditions followed by a gradual amelioration during a stadial period (see Fig. 10). Seidenkrantz (1993a, 1993b) named this stadial the "Kattegat Stadial". The Younger Dryas-type oscillation at the stage 6/5e transition (the Zeifen-Kattegat oscillation) has now been recorded in a number of marine and terrestrial sequences both in the Northern and Southern Hemisphere (Seidenkrantz et al. in press).

The boundary between Zone $\mathrm{D}$ and Zone $\mathrm{E}$ in the
Anholt cores marks the transition between the Saalian Glacial (stage 6) and the Eemian interglacial (substage 5e). In Zone $E$ the arctic and subarctic components of the fauna of Zones $\mathrm{C}$ and $\mathrm{D}$ are gradually replaced by boreal and lusitanian species, which become established in Zones $F$ and $G$. The dominance of boreal and lusitanian species such as Bulimina aculeata d'Orbigny and Bulimina marginata (grouped together as $B$. marginata in the North Jutland cores) as well as Cassidulina laevigata carinata Silvestri (called $C$. laevigata in the North Jutland cores) and the presence of a few specimens of Quinqueloculina padana in Zones F and $\mathrm{G}$ demonstrate fully interglacial conditions in this interval (Figs. 7, 8).

The Eemian at Anholt is overlain by sand and nonmarine, varved clay, which is succeeded by about $2 \mathrm{~m}$ of marine clay (Fig. 7). This marine unit has been correlated 


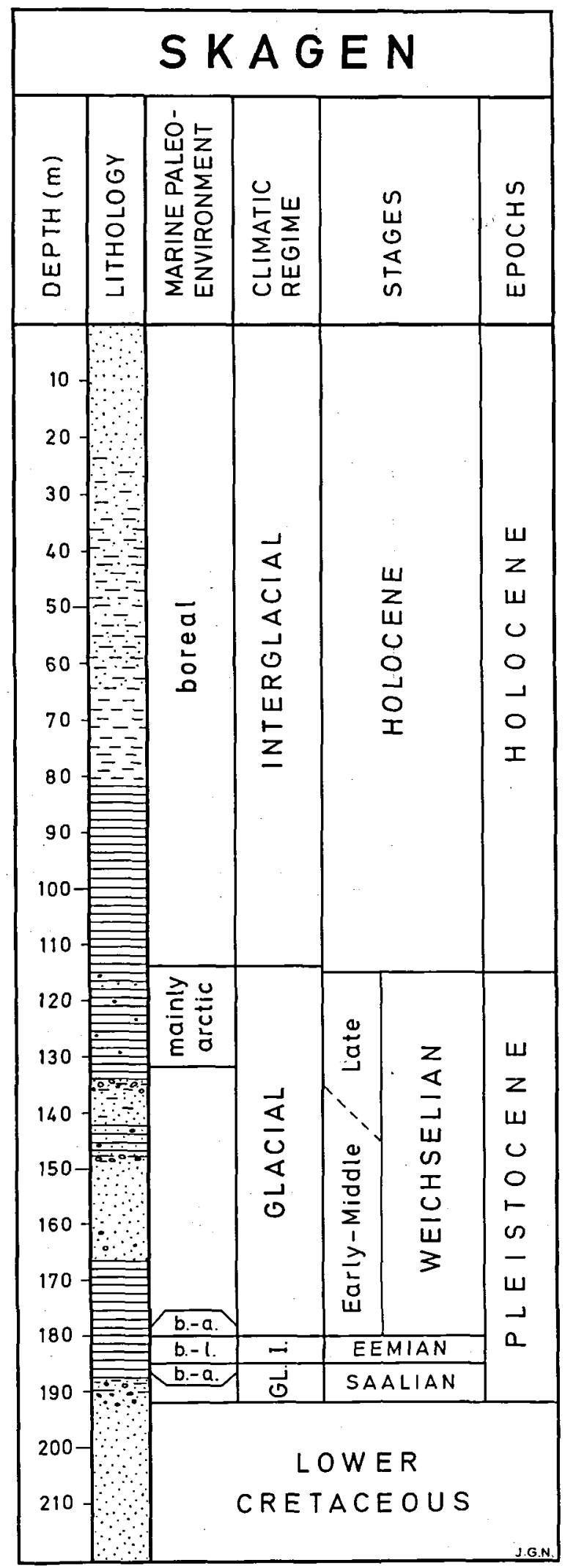

with part of the Middle Weichselian sequence in the Skærunhede sequence (Seidenkrantz 1993b).

The marine interval is succeeded by fossil-free silty clay and a sequence contaning a high concentration of reworked Quaternary foraminifera. This sequence, which mainly consists of silt and sandy silt, is interpreted as a fluvial deposit from the Middle Weichselian (Seidenkrantz 1993b; Lykke-Andersen et al. 1993c).

\section{The Skagen cores}

The following review of the stratigraphy at Skagen is a short compilation of unpublished results from ongoing studies of material from two new boreholes at Skagen (Fig. 3), which were carried out in 1992 and 1993. The core material is being studied as a joint research project by the GeoKat group at the Department of Earth Sciences, University of Aarhus in cooperation with 'The Skagen Spit project - nature and culture', the Geological Survey of Denmark, the University of Aalborg, Kampsax Geodan in Aalborg, the University of Quebec in Montreal and the University of Cambridge.

Some preliminary results from Skagen are shown in Fig. 9. The lithology refers to descriptions of the cores by Ole Bjørslev Nielsen. The stratigraphy is based on results of foraminiferal analyses carried out by Marit-Solveig Seidenkrantz, Keld Conradsen and the present author, supplemented by AMS ${ }^{14} \mathrm{C}$-dates from the Late Weichselian and Holocene part of the sequence. These are carried out by Susanne Heier Nielsen and Jan Heinemeier at the AMS Accellerator Laboratory in Århus.

The boreholes at Skagen (Skagen 3 and 4) were carried out in order to obtain cored material from which a better understanding of the Quaternary geological development in the region could be obtained. Previous studies of cuttings from an exploration well (Skagen 2) at Skagen had revealed Eemian foraminiferal assemblages in the deeper part of the Quaternary sequence, and it was inferred that the Holocene sequence had a thickness of more than 100 $m$ (Knudsen 1985b). This, together with the fact that Skagen is located close to the central part of the Kattegat Depression, also made it a promising core location for the establishment of a point of reference for the interpretation of reflection seismic profiles in Kattegat (Lykke-Andersen et al. 1993a, 1993b).

The Skagen 3 borehole was c. $220 \mathrm{~m}$ deep. A core recovery of $74 \%$ was obtained between 30 and $220 \mathrm{~m}$ depth, and a supplementary core covered the uppermost

Fig. 9. The Quaternary sequence in the Skagen 3 and 4 cores. The stratigraphical subdivision and the palaeoenvironmental interpretations are based on preliminary results of ${ }^{14} \mathrm{C}$ datings and foraminiferal analyses (partly from Susanne Heier Nielsen, Keld Conradsen and Marit-Solveig Seidenkrantz, personal communications). Lithology is based on descriptions by Ole Bjørslev Nielsen (personal communication). Legend for lithology, see Fig. 7. 
c. $30 \mathrm{~m}$ (Skagen 4). The stratigraphy illustrated in Fig. 9 combines the results from both the Skagen 3 and the Skagen 4 borehole. The core sites are both $1.0 \mathrm{~m}$ above present day sea level.

An about $25 \mathrm{~m}$ thick sandy sequence with layers of lignite at the bottom of the core is referred to Lower Cretaceous (Fig. 9). The lowermost part of the Quaternary sequence consists of mainly glacigenic sands and clays, which are presumed to be Saalian in age. A diamict sediment with a high concentration of pebbles and stones occurs within this unit.

Foraminiferal studies show that a marine transgression occurred towards the end of the Late Saalian and that marine conditions persisted in the area through the Eemian Interglacial, which is represented by $5 \mathrm{~m}$ of clay. The interglacial foraminiferal assemblages represent a deep water facies of the Eemian, and they reflect marked temperature oscillations in the upper third of the sequence (Fig. 10). Details of these environmental indications are being compared closely with results from the GRIP ice core in Greenland (GRIP Members 1993, Seidenkrantz \& Knudsen 1994). Continuous marine sedimentation seems to have occurred across the Eemian-Early Weichselian boundary and into the Early Weichselian (c. $2 \mathrm{~m}$ ).

The marine Saalian-Eemian-Early Weichselian sequence at Skagen is succeeded by c. $55 \mathrm{~m}$ of clay and sand with scattered ice-rafted pebbles and stones. This unit contains a relatively high concentration of reworked Quaternary foraminifera. It presumably represents fluvial sediments deposited into the marine basin from the southeast during the Middle Weichselian (see also LykkeAndersen et al. 1993c; Lykke-Andersen in press). A marked concentration of pebbles and stones in the upper part of this basin filling sediment probably indicates the Main Weichselian glaciation. However, it is not clear yet, if this diamict sediment represents a glaciomarine deposit with numerous ice-rafted debris, or if it might represent a glacial till.

Marine conditions were re-established in the area at about $15,000 \mathrm{BP}$, i.e. from c. $132 \mathrm{~m}$ depth in the core (Fig. 9). A c. $18 \mathrm{~m}$ thick marine clay with scattered stones contains mainly arctic foraminiferal assemblages with a clear indication that the climatic Allerød-Younger Dryas oscillation had a marked influence on the marine environment in the northernmost part of Kattegat. Furthermore, the Weichselian-Holocene transition is represented in the Skagen core, and the environmental changes across the boundary are being closely examined on the basis of foraminiferal content and oxygen isotope analyses.

The extremely thick (114 m, Fig. 9) presumably continuous marine Holocene sequence consists of clay in the lower part and gradually more silty and sandy sediments towards the top. The studies of this Holocene sequence appear to add valuable new information relating to the problem of environmental changes and their association with paleoceanography of the area, and a detailed chronostratigraphical framework for the sequence of events is established on the basis of AMS ${ }^{14} \mathrm{C}$-dates.
Saalian to Holocene paleoecology in northern Denmark

On the basis of the studies of cores and sections in the North Jutland-Kattegat area in combination with seismic studies in the area it has been possible to obtain knowledge of the geological development and the paleoecology of the whole region.

An outline of the paleoenvironmental development in the area during the Saalian, Eemian and Early to Middle Weichselian is shown in Fig. 10. The temperature indications and the approximate depth indication of foraminiferal assemblages in Northern Denmark are shown together with stratigraphical correlations with the deep-sea oxygen isotope stages of Martinson et al. (1987).

After the Zeifen-Kattegat climatic oscillation towards the end of the Saalian there was a rapid rise in both temperature and in water depth in the beginning of the Eemian. New evidence from the Skagen core suggests that-the greatest water depth was reached during the earliest third of the Eemian, and that the water became relatively shallower during the remaining two-thirds of the interglacial. This means that the previous interpretation of a relatively later high sea level, which was based on data from Apholm and Anholt (Seidenkrantz \& Knudsen 1994), probably has to be revised. Any further indications of depth oscillations in the Eemian record at Skagen are, however, not yet clear.

Previous studies of the Eemian foraminiferal assemblages have suggested that this was a period of uninterrupted warm, stable conditions (Knudsen 1992; Seidenkrantz \& Knudsen in press). In contrast to this, the pollen evidence from NW Europe would indicate an early maximum temperature for the Eemian, about 3000 years after the beginning of the interglacial (Müller 1974), and a subsequent gradual decrease in winter temperature. This temperature maximum, thus, seems to occur prior to the maximum global sea level (see Shackleton 1987; Martinson et al. 1987).

New evidence from the Summit ice core in Greenland suggest that the last interglacial in fact was a period of extensive climatic variability (GRIP Members 1993). The high resolution foraminiferal studies of the Eemian at Skagen show that the period was mainly characterized by temperatures that were slightly warmer than at present. However, there is a strong faunal indication that this warm temperate climate was interrupted by a period with colder conditions about two thirds into the interglacial (Seidenkrantz \& Knudsen 1994) (Fig. 10). The gradual decrease in water depth indicated by the foraminiferal assemblages at Apholm and Skærumhede towards the end of the Eemian presumably points to an initial growth of polar ice prior to the Eemian-Weichselian transition.

The Eemian-Weichselian boundary was characterized by a major drop in sea level and a temperature decrease from lusitanian to boreal-arctic conditions, but the final change to fully glacial conditions did not occur until the Early/Middle Weichselian boundary (Knudsen 1992; Seidenkrantz \& Knudsen in press) (Fig. 10). 


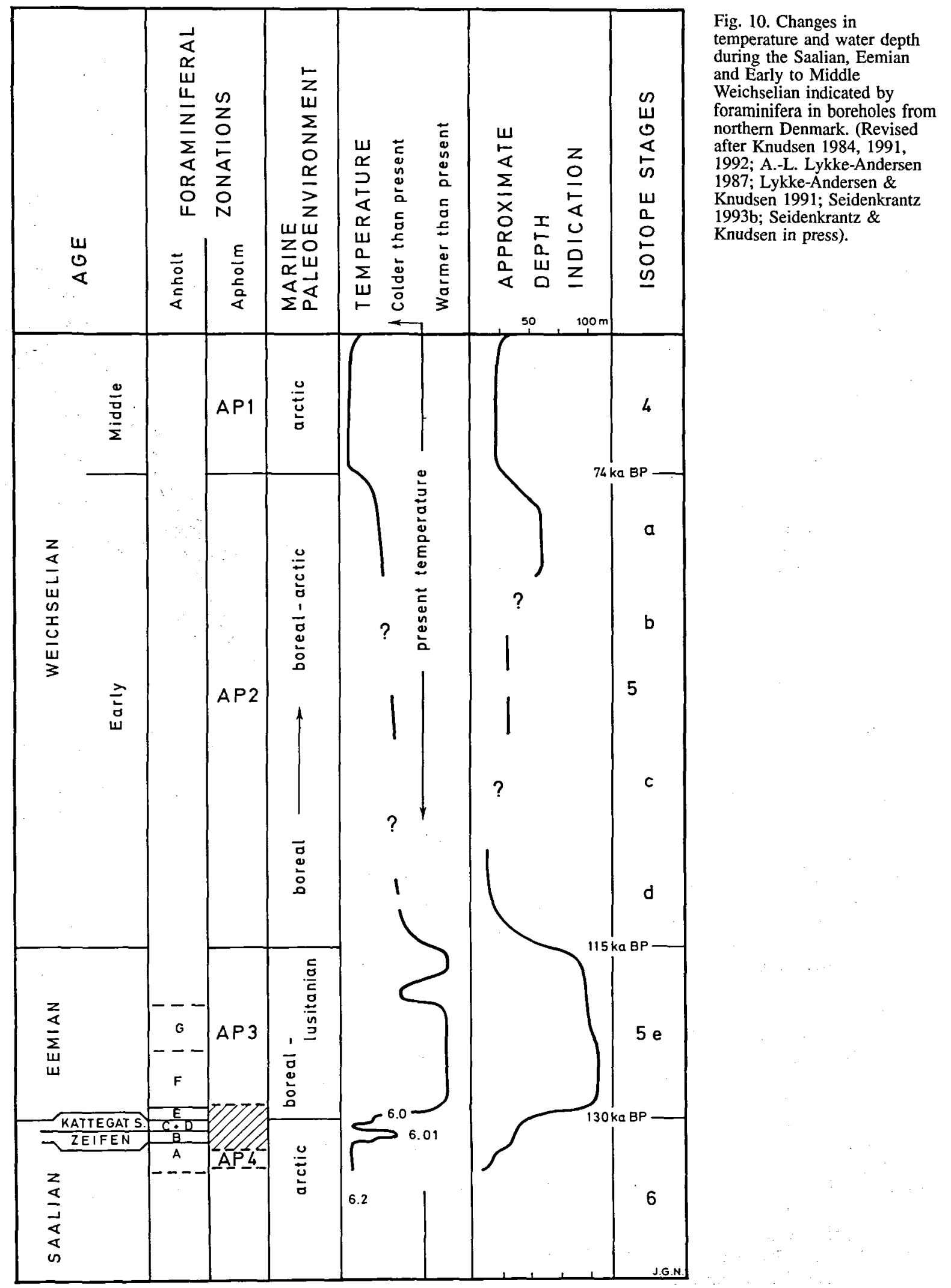


Due to the lack of a direct correlation of the present marine sequences with the regional pollen stratigraphy, an exact chronology for the succession of events in the marine environment during the Eemian and Early Weichselian cannot be established yet. However, pollen studies of the marine sequences are in progress.

The North Jutland and Kattegat region is characterized by relatively thick sequences of both marine and nonmarine sediments from the Middle Weichselian. Marine sequences from the Middle Weichselian are common in part of North Jutland. In this area they are usually succeeded by fluvial deposits (e.g., Lykke-Andersen 1971, 1982; Konradi \& Knudsen 1974; Knudsen 1985b; LykkeAndersen \& Knudsen 1991). Further to the east and south, however, fluvial sediments seem to be dominant (e.g., on Læs $\varnothing$ and on Anholt (Knudsen 1986b; Seidenkrantz 1993b; Lykke-Andersen et al. 1993c)), even though marine intervals are often registered in this area as well (e.g., Bergsten \& Nordberg 1993; Seidenkrantz \& Knudsen 1993; Nielsen \& Konradi 1990; Konradi 1992). At Skagen, which is located closer to the central part of the depositional basin, the entire Middle Weichselian sequence is represented by fluvial deposits.

According to seismic studies from the area (Gyldenholm et al. 1993; Lykke-Andeersen in press), this Middle Weichselian sequence seems to have been deposited by the transport of large amounts of fluvial material into the marine northwest-southeast trending basin from the southeast. Due to the extremely high supply of sediment loaded freshwater to the area there is no faunal indication of marine conditions, and only reworked faunas are found in the sediments.

Additional studies of the marine development in the Late Weichselian and the Holocene are in progress, especially in connection with studies of the Skagen boreholes and short cores from the Kattegat.

Foraminiferal assemblages and ${ }^{14} \mathrm{C}$ dates indicate that marine conditions returned to the Skagen area at $\mathrm{c}$. $15,000 \mathrm{BP}$, whereas the maximum marine inundation in the Kattegat seems to have occurred at about 13,50013,000 BP (e.g., Petersen 1985a, 1985b). Evidence for the drainage of the Baltic Ice Lake through the Øresund Strait from about 12,700 BP has been described by Bergsten \& Nordberg (1992) from the southern Kattegat, but this event has not yet been registered further north in the area. The climatic Allerød-Younger Dryas oscillation is, however, registered for the first time in marine deposits in Denmark in the Skagen core, where marine environmental changes are evidenced by marked faunal changes towards the end of the Late Weichselian. A review of paleoceanographic conditions over the last 8000 years in the Kattegat-Skagerrak region has recently been given by Nordberg \& Bergsten (1988) and Nordberg (1991). They conclude that the present circulation system in the Kattegat was presumably established by about 4000 years $\mathrm{BP}$ and that minor modifications occurred at about 2000, 1000-500 and $300 \mathrm{BP}$. As the marine Holocene sedimentation in the area seems to be characterized by changing periods of deposition and non-deposition, no continuous records have been described from the area yet (Knudsen \& Nordberg 1987; Bergsten \& Nordberg 1988; Nordberg 1989, 1991; Conradsen 1992; Christiansen et al. 1993). Ongoing studies of the apparently continuous $114 \mathrm{~m}$ thick Holocene sequence at Skagen, however, seem to add valuable new information, which will enable a better understanding of environmental changes during the Holocene and to the dating of the paleoenvironmental events in the area.

\section{Acknowledgements}

This study summarizes results from several projects, but much of the new information has been obtained in the framework of the GeoKat project, which was financed mainly by the Danish Natural Science Research Council. Additional funding was given to the Skagen boreholes by the municipality of Skagen. I am grateful to Keld Conradsen, Ole Bjørslev Nielsen, Susanne Heier Nielsen and Marit-Solveig Seidenkrantz, who let me use unpublished data from the Skagen 3 borehole. My sincere thanks also to Jette Gissel Nielsen, who prepared the drawings, to David N. Penney, who corrected the English of the text and to Peter Konradi and Kjell Nordberg, who gave valuable comments on the manuscript.

\section{Dansk sammendrag}

Der er en del usikkerhed omkring den stratigrafiske indplacering af de ældste marine kvartære aflejringer i Danmark. Boringer fra Nordsøen viser, at man her har haft marine forhold allerede i visse perioder af Tidlig Pleistocæn. På land i Danmark er der derimod endnu ikke fundet marine kvartare sedimenter, som er ældre end Mellem Pleistocæn. Der har været en tendens til, at alle aflejringer med arktiske faunaer, som ser ud til at være ældre end Holstein Interglacial tid, er blevet indplaceret i Elster. Absolutte dateringer af nogle af disse tyder imidlertid på, at også aflejringer ældre end Elster kan være repræsenteret indenfor denne "gruppe".

Sedimenter fra sen Elster-Holstein transgressionen er specielt rigt repræsenteret $i$ den vestlige og sydvestlige del af Danmark. Udbredelsen synes at være knyttet til områder med dybtliggende præ-Kvartær overflade. Rei sultater af aminosyre dateringer på foraminiferer fra Holstein aflejringer både fra Danmark og Tyskland og fra boringer i Nordsøen tyder på, at en korrelation med oxygen isotop stage 7 er mest sandsynlig. Palæo $\varnothing$ kologiske korrelationer med det Nordatlantiske område peger i samme retning.

Marine aflejringer fra Eem Interglacial tid (substage 5e) er reprasenteret over store dele af Danmark. I de sydlige og sydvestlige områder, hvor en lavtvandsfacies af Eem er reprasenteret, strakte den marine transgression sig kun over et relativt kort tidsrum. Kun en del af den 
interglaciale periode er repræsenteret $\mathrm{i}$ de marine sedimenter her. I det nordlige Jylland og $\mathrm{i}$ store dele af Kattegat området, der i sen Mellem Pleistocæn udgjorde en dyb nordvest-sydøst orienteret bassinstruktur, startede transgressionen derimod allerede i Sen Saale og sedimentationen fortsatte gennem hele Eem og langt ind i Weichsel.

På baggrund af foraminifer-undersøgelser fra en ny boring på Anholt, er der påvist klimatiske oscillationer ved slutningen af Saale (Zeifen Interstadial og Kattegat Stadial), der kan sammenlignes med Allerød-Yngre Dryas oscillationen i slutningen af Weichsel. Tilsvarende svingninger er også påvist $\mathrm{i}$ dybhavskerner både på den sydlige og nordlige halvkugle, $i$ terristriske aflejringer, samt i GPIP iskernen på Grønlend.

Faunaerne i Eem sedimenterne indeholder lusitanske elementer, som viser, at temperaturen har været nogle få grader højere end i dag. Fauna-variationer i Eem lagserien ved Skagen indikerer temperatursvingninger, som ser ud til at kunne korreleres med tilsvarende oscillationer indenfor Eem i GRIP iskernen på Grønland.

Vanddybden synes at nå sit maximum relativt tidligt $\mathrm{i}$ Eem, og det er bemærkelsesværdigt, at vanddybden begyndte at aftage henimod slutningen af Eem - før overgangen til Weichsel. Dette tyder på, at opbygningen af is på polerne må vare startet allerede i slutningen af Eem Interglacial tid. En komplet lagserie af marine sedimenter fra overgangen mellem Eem og Tidlig Weichsel er specielt godt repræsenteret i Skagen 3 boringen, som er under bearbejdelse.

I Mellem Weichsel var store dele af Kattegat området præget af fluvial sedimentation. Marine aflejringer fra denne periode er især kendt fra det nordlige Jylland, men enkelte tynde marine indslag er $\operatorname{dog}$ også registreret $i$ boringer i Kattegat området. Mere centrale områder af bassinet (f.eks. ved Skagen) er derimod specielt præget af non-marin sedimentation. En ekstrem stor tilførsel af sediment synes således gradvist at have udfyldt bassinet fra sydøst og tilsløret ethvert tegn på marine forhold i området.

Den meget tykke marine lagserie fra sen Weichsel (ca. $18 \mathrm{~m}$ ) og Holocæn (ca. $114 \mathrm{~m}$ ), som er repræsenteret ved Skagen, er basis for detaljerede undersøgelser af den palæoøkologiske udvikling gennem de seneste ca. 15,000 år. Foraminifer-indholdet $i$ lagserien afspejler markante klimasvingninger og oceanografiske ændringer i området ikke blot i slutningen af Weichsel (Allerød-Yngre Dryas) og ved overgangen til Holocæn, men også flere gange $\mathbf{i}$ løbet af Holocæn tid. Miljøændringernes tidsmæssige indplacering bestemmes ved hjælp af en serie AMS ${ }^{14} \mathrm{C}$ dateringer.

\section{References}

Andersen, S. T. 1963: Pollen Analysis of the Quaternary Marine Deposits at Tornskov in South Jutland. Danmarks Geologiske Undersøgelse IV Række 4(8), 1-23.
Andersen, S. T. 1965: Interglacialer og interstadialer i Danmarks kvartær. Meddelelser fra dansk geologisk Forening 15, 486504.

Bergsten, H. \& Nordberg, K. 1992: Late Weichselian marine stratigraphy of the southern Kattegat, Scandinavia: evidence for drainage of the Baltic ice lake between 12,700 and 10,300 yrs BP. Boreas 21, 223-252.

Bergsten, H. \& Nordberg, K. 1993: Middle Weichselian marine sediments from eastern Kattegat, Scandinavia. Boreas 22, 311-318.

Bruun-Petersen, J. 1990: Det brune grundvand i Ribe amt. Dansk geologisk Forening, Årsskrift for 1987-89, 103-107.

Buch, A. 1955: De marine interglaciale lag ved Inder Bjergum. Foraminiferfauna og stratigrafi. Meddelelser fra dansk geologisk Forening 12, 593-652.

Buch, A. 1972: Undersøgelser over det marine Kvartær i Nordsøområdet. Dansk geologisk Forening, Årsskrift for 1971, $86-90$.

Chappell, J. \& Shackleton, N. J. 1986: Oxygen isotopes and sea level. Nature 324, 137-140.

Christiansen, C., Conradsen, C., Emelyanov, E., Trimonis, E., Heinemeier, J. \& Rud, N. 1993: Hydrographic changes in the southern Kattegat (Scandinavia) during the early Holocene transgression. Boreas 22, 349-356.

Conradsen, K. 1992: Holocæne foraminiferfaunaer fra en borekerne i det sydlige Kattegat. Dansk geologisk Forening, Årsskrift for 1990-91, 89-91.

Conradsen, K., Bergsten, H., Knudsen, K. L., Nordberg, K. \& Seidenkrantz, M.-S. 1994: Recent benthic foraminiferal distribution in the Kattegat and the Skagerrak, Scandinavia. Cushman Foundation for Foraminiferal Research, Special Publication 32, 53-68.

Feyling-Hanssen, R. W. 1955: Stratigraphy of the marine LatePleistocene of Billefjorden, Vestspitsbergen. Norsk Polarinstitutt Skrifter 107, 1-186.

GRIP Members (Greenland Ice Core Project) 1993: Climate instability during the last interglacial period recorded in the GRIP ice core. Nature 364, 203-207.

Gyldenholm, K., Lykke-Andersen, H. \& Lind, G. 1993: Seismic stratigraphy of the Quaternary and its substratum in the southeastern Kattegat, Scandinavia. Boreas 22, 319-327.

Jensen, J. B. \& Knudsen, K. L. 1984: Kvartærstratigrafiske undersøgelser ved Gyldendal og Kås Hoved i det vestlige Limfjordsområde. Dansk geologisk Forening, Årsskrift for 1983, 35-54.

Knudsen, K. L. 1977: Foraminiferal faunas of the Quaternary Hostrup Clay from Northern Jutland, Denmark. Boreas 6, 229-245.

Knudsen, K. L. 1984: Foraminiferal stratigraphy in a marine Eemian-Weichselian sequence at Apholm, North Jutland. Bulletin of the Geological Society of Denmark 32, 169-180.

Knudsen, K. L. 1985a: Foraminiferal stratigraphy of Quaternary deposits in the Roar, Skjold and Dan Fields, central North Sea. Boreas 14, 311-324.

Knudsen, K. L. 1985b: Correlation of Saalian, Eemian and Weichselian foraminiferal zones in North Jutland. Bulletin of the Geological Society of Denmark 33, 325-339.

Knudsen, K. L. 1985c: Foraminiferal faunas in Eemian deposits of the Oldenbüttel area near the Kiel Canal, Germany. Geologisches Jahrbuch A86, 27-47.

Knudsen, K. L. 1986a: Middle and Late Quaternary Foraminiferal Stratigraphy in the Southern and Central North Sea Area. Striae 24, 201-205.

Knudsen, K. L. 1986b: Foraminifer-stratigrafisk unders $\emptyset$ gelse af marint Weichsel på Læsø. In Bahnson, H., Knudsen, K. L. \& Hansen, J. M.: Læs $\emptyset$ 's Geologi. Lithologi, Biostratigrafi og Geofysik. Danmarks Geologiske Undersøgelse Serie D 6, 29.46.

Knudsen, K. L. 1987a: Foraminifera in the Late Elsterian- Holsteinian sequence at Tornskov in South Jutland, Denmark. Danmarks Geologiske Undersøgelse Serie B 10, 7-31.

Knudsen, K. L. 1987b: Elsterian-Holsteinian foraminiferal stra- 
tigraphy in the North Jutland and Kattegat areas, Denmark. Boreas 16, 359-368.

Knudsen, K. L. 1988: Marine Interglacial Deposits in the Cuxhaven Area, NW Germany: A comparison of Holsteinian, Eemian and Holocene Foraminiferal Faunas. Eiszeitalter und Gegenwart 38, 69-77.

Knudsen, K. L. 1991: Marine Eemian and Early Weichselian deposits in Northern Denmark - a review of the foraminiferal stratigraphy. Quaternary International 10-12, 167-171.

Knudsen, K. L. 1992: A long marine Eemian-Weichselian shelf record in North Denmark, Scandinavia. In Kukla, G. J. \& Went, E. (eds.) Start of a Glacial. NATO ASI Series I 3. Springer-Verlag Berlin Heidelberg, 157-171.

Knudsen, K. L. 1993: Late Elsterian-Holsteinian Foraminiferal Stratigraphy in Boreholes in the Lower Elbe Area, NW Germany. Geologisches Jahrbuch A138, 97-119.

Knudsen, K. L. \& Lykke-Andersen, A.-L. 1982: Foraminifera in Late Saalian, Eemian, Early and Middle Weichselian of the Skærumhede I boring. Bulletin of the Geological Society of Denmark 30, 97-109.

Knudsen, K. L. \& Nordberg, K. 1987: Late Weichselian and Holocene biostratigraphy in borings southeast of Frederikshavn, Denmark. Bulletin of the Geological Society of Denmark 36, 289-303.

Knudsen, K. L. \& Sejrup, H. P. 1988: Amino acid geochronology of selected interglacial sites in the North Sea area. Boreas $17,347-354$.

Koç, N., Jansen, E. \& Haflidason, H. 1993: Paleoceanographic reconstructions of surface ocean conditions in the Greenland, Iceland and Norwegian Seas through the last $14 \mathrm{ka}$ based on diatoms. Quaternary Science Reviews 12, 115-140.

Konradi, P. B. 1976: Foraminifera in Eemian deposits at Stensigmose, southern Jutland. Danmarks Geologiske Unders $\emptyset$ gelse II Række 105, 1-57.

Konradi, P. B. 1992: De marine Kvartære aflejringer i Esrumdalen. Dansk geologisk Forening, Årsskrift for 1990-91, $111-115$.

Konradi, P. B. \& Knudsen, K. L. 1974: Foraminifera in the Skærumhede II boring. In Bahnson, H., Petersen, K. S., Konradi, P. B. \& Knudsen, K. L. Stratigraphy of Quaternary deposits in the Skærumhede II boring: lithology, molluscs and foraminifera. Danmarks Geologiske Unders $\emptyset$ gelse, Årbog $1993,43-57$.

Kronborg, C. \& Knudsen, K.L, 1985: Om Kvartæret ved Rugård: En foreløbig undersøgelse. Dansk geologisk Forening, Årsskrift for 1984, 37-48.

Lafrenz, H. R. 1963: Foraminiferen aus dem marinen RissWürm-Interglazial (Eem) in Schleswig-Holstein. Meyniana $13,10-46$.

Linke, G., Katzenberger, O. \& Grün, R. 1985: Description and ESR Dating of the Holsteinian Interglaciation. Quaternary Science Reviews 4, 319-331.

Lykke-Andersen, A.-L. 1971: Foraminifera from the Older Yoldia Clay in Hirtshals. In Feyling-Hanssen, R. W., Jørgensen, J. A., Knudsen, K. L. \& Lykke-Andersen, A.-L. 1971: Late Quaternary Foraminifera from Vendsyssel, Denmark and Sandnes, Norway. Bulletin of the Geological Society of Denmark 21, 159-184.

Lykke-Andersen, A.-L. 1982: Nogle nye C-14 dateringer fra EEldre Yoldia Ler i Hirtshals Kystklint. Dansk geologisk Forening, Årsskrift for 1981, 119-121.

Lykke-Andersen, A.-L. 1987: A Late Saalian, Eemian and Weichselian marine sequence at Nørre Lyngby, Vendsyssel, Denmark. Boreas 16, 345-357.

Lykke-Andersen, A.-L. 1990: Marine aflejringer fra Sen Elster på Sjælland. Dansk geologisk Forening, A Arsskrift for 1987-88, 77-80.

Lykke-Andersen, A.-L, \& Knudsen, K. L. 1991: Saalian, Eemian and Weichselian in the Vendsyssel-Kattegat Region, Denmark. In Andersen, B. G. \& Königsson, L.-K. (eds.) Late Quaternary Stratigraphy in the Nordic Countries 150,000 15,000 . Striae $34,135-140$.
Lykke-Andersen, H. 1987: Thickness of the Quaternary deposits and their relation to the pre-Quaternary in the Fennoscandian border zone in Kattegat and Vendsyssel. Boreas 16, 369-371.

Lykke-Andersen, $\mathrm{H}$. in press: Contributions to the Geology of Kattegat and Vendsyssel - a study of the pre-Quaternary and Quaternary structures based on seismic data and outcrop observations. Danmarks Geologiske Undersøgelse Serie A.

Lykke-Andersen, H., Knudsen, K. L. \& Christiansen, C. 1993a: The GeoKat project - a study of the Late Quaternary evolution of the Kattegat Sea. Boreas 22, 267-268.

Lykke-Andersen, H., Knudsen, K. L. \& Christiansen, C. 1993b: The Quaternary of the Kattegat area, Scandinavia: a review. Boreas 22, 269-281.

Lykke-Andersen, H., Seidenkrantz, M.-S. \& Knudsen, K. L. 1993c: Quaternary sequences and their relations to the preQuaternary in the vicinity of Anholt, Kattegat, Scandinavia. Boreas 22, 291-298.

Mangerud, J., Sønstegaard, E. \& Sejrup, H. P. 1979: Correlation of the Eemian (interglacial) Stage and the deep-sea oxygenisotope stratigraphy. Nature $277,189-192$.

Mangerud, J., Sønstegaard, E., Sejrup, H. P. \& Haldorsen, S. 1981: A continuous Eemian-Early Weichselian sequence containing pollen and marine fossils at Fjøsanger, western Norway. Boreas 10, 137-203.

Martinson, D. G., Pisias, N. G., Hays, J. D., Imbrie, J., Moore, Jr., T. C. \& Shackleton, N. J. 1987: Age Dating and Orbital Theory of the Ice Ages: Development of high-resolution 0 to 300.000 years chronostratigraphy. Quaternary Research 27, $1-29$.

Miller, G. H. \& Mangerud, J. 1986: Aminostratigraphy of European marine interglacial deposits. Quaternary Science Reviews $4,215-278$.

Müller, H. 1974: Pollenanalytische Untersuchungen und Jahresschichtenzählungen an der eem-zeitlichen Kiselgur von Bispingen/Luhe. Geologisches Jahrbuch A21, 149-169.

Nielsen, O. B. 1992: Lithologi, lithostratigrafi og aflejringsmiljø i Anholtboringen. Dansk geologisk Forening, Arsskrift for 1990-91, 67-72.

Nielsen, P. E. \& Konradi, P. B. 1990: Seismic stratigraphy and foraminifera in Late Quaternary deposits, southern Kattegat, Denmark. Striae 29, 105-110.

Nordberg, K. 1989: Sea-floor deposits, paleoecology and paleohydrography in the Kattegat during the later part of the Holocene. Department of Geology, Chalmers University of Technology and University of Göteborg A 65, 205 pp.

Nordberg, K. 1991: Oceanography in the Kattegat and Skagerrak over the past 8000 years. Paleoceanography $6,461-484$.

Nordberg, K. \& Bergsten, H. 1988: Biostratigraphic and sedimentological evidence for hydrographic changes in the Kattegat during the later part of the Holocene. Marine Geology 83, 135-158.

Penney, D. N. 1987: Ostracoda of the Holsteinian Interglacial in Jutland, Denmark. Danmarks Geologiske Undersøgelse Serie B 10, 33-67.

Penney, D. N. 1990: Microfossils (Foraminifera, Ostracoda) from an Eemian (Last Interglacial) tidal flat sequence in south-west Denmark. Quaternary International 3/4, 85-91.

Petersen, K. S. 1985a: Late Weichselian and Holocene marine transgressions in Northern Jutland, Denmark. Eiszeitalter und Gegenwart 35, 71-78.

Petersen, K. S. 1985b: The Late Quaternary history of Denmark. The Weichselian ice sheet and land/sea configuration in the Late Pleistocene and Holocene. Journal of Danish Archaeology $4,7-22$.

Salomonsen, I. \& Jensen, K. A. in press: Quaternary erosional surfaces in the Danish North Sea. Boreas 23.

Seidenkrantz, M.-S. 1992: Nye oplysninger om Kvartær stratigrafi - baseret på foraminiferer fra en ny boring på Anholt, Kattegat. Dansk geologisk Forening, Årsskrift for 1990-91, 81-88.

Seidenkrantz, M.-S. 1993a: Benthic foraminiferal and stable isotope evidence for a "Younger Dryas-style" cold spell at the 
Saalian-Eemian transition, Denmark. Palaeogeography, Palaeoclimatology, Palaeoecology 102, 103-120.

Seidenkrantz, M.-S. 1993b: Foraminifera from the Quaternary sequence in the Anholt boring, Denmark. Boreas 22, 283290.

Seidenkrantz, M.-S., Bornmalm, L., Johnsen, S. J., Knudsen, K. L., Kuijpers, A., Lauritzen, S. E., Leroy, S. A. G., Mergeai, I., Schweger, C. \& Van Vliet-Lanoë, B. in press: Two-step deglaciation at the oxygen isotope stage 6/5e transition: the Zeifen-Kattegat climatic oscillation. Quaternary Research.

Seidenkrantz, M.-S. \& Knudsen, K. L. 1993: Middle Weichselian to Holocene palaeoecology in the Eastern Kattegat, Scandinavia: foraminifera, ostracods and ${ }^{14} \mathrm{C}$ measurements. Boreas 22, 299-310.

Seidenkrantz, M.-S. \& Knudsen, K. L. 1994: Benthic foraminiferal evidence of a mid-last interglacial cold period at Skagen, Denmark. Abstract, 24th Arctic Workshop, March 17-19, Boulder, Colorado, 82.

Seidenkrantz, M.-S. \& Knudsen, K. L. in press: Marine high resolution records of the last interglacial in northwest Europe: a review. Géographie physique et Quaternaire 48(2).

Sejrup, H. P. \& Knudsen, K. L. 1993: Paleoenvironments and correlations of interglacial sediments in the central and northern North Sea. Boreas 22, 223-235.

Shackleton, N. J. 1969: The last interglacial in the marine and terrestrial records. Proceedings of the Royal Society of London B 174, 135-154.

Shackleton, N. J. 1987: Oxygene isotopes, ice volumes and sea level. Quaternary Science Reviews 6, 183-190.

Streif, H. 1984: Outline of the Pleistocene development in northwestern Germany. In: North Sea Coastal Zone between Jade Bay and Jammer Bight. Excursion Guide, INQUA Subcommission on Shorelines of Northwestern Europe, Field Conference 1984, Sept. 15-21, 1-6.

Turon, J. L. 1984: Direct land/sea correlations in the last interglacial complex. Nature 309, 673-676.

Van Voorthuysen, J. H. 1957: Foraminiferen aus dem Eemian (Riss-Wurm Interglacial) in der Bohrung Amersfoort I (locus typicus). Mededelingen van de Geologische Stichting, Niewe Serie 11, 27-39.

Wiegank, F. 1972: Ökologische Analyse quartärer Foraminiferen. Beitrag zur Quartär-stratigraphie in der nördlichen Deutschen Demokratischen Republik. Geologie 77, 1-111.

Zagwijn, W. H. 1977: Sea level changes during the Eemian in the Netherlands. Xth INQUA Congress, Birmingham 1977, Abstracts, 509 .

Zagwijn, W. H. 1983: Sea-level changes in the Netherlands during the Eemian. In Van den Berg, M. W. \& Felix, R. (eds.) Special issue in honour of J.D. de Jong. Geologie en Mijnbouw $62,437-350$. 